\title{
Quadro Helix Engagement in Developing the Creative City of Malang: A Public Relations Model Approach
}

\author{
Prayudi $^{1 *}$, Kartika Ayu Ardhanariswari ${ }^{2}$, Ninik Probosari ${ }^{3}$ \\ ${ }^{12}$ Department of Communication Science, Universitas Pembangunan Nasional Veteran Yogyakarta, Indonesia \\ ${ }^{3}$ Department of Management, Universitas Pembangunan Nasional Veteran Yogyakarta, Indonesia \\ ${ }^{*}$ Corresponding author. Email: prayudi@upnyk.ac.id
}

\begin{abstract}
Adequate support is needed for creative cities with significant economic potentials and identity. This idea tends to increase the added value and competitiveness of these cities, thereby making them a center of growth for the community and the surrounding area. The purpose of this study is to analyze the development of Malang, Indonesia, as a creative city using the Quadro helix and public relations model approaches. The Quadro helix approach suggests that developing a creative city is associated with the cooperation of Academic, Business, Community, and Government (ABCG). Meanwhile, the public relations model suggests four models of communication in planning programs. This study also applied the qualitative research methods with in-depth interviews and focus group discussions on collecting data from the ABCG actors. The results showed that engagement, response communication, and public information models are the three models adopted for communication among creative actors. The availability of a forum that incorporates relevant creative actors is essential because the game and application act as the leading sub-sector of the creative city of Malang. Furthermore, it adopts various communication technics to inform, consult, collaborate, and empower relevant actors. The local government also shows its support through the provision of regulation and creative infrastructure. Meanwhile, academics collaborate with the business sector, and support from the government provides relevant programs that enhance the economy of creative community groups.
\end{abstract}

Keywords: communication, creative city, engagement, public relations model, quadro helix

\section{INTRODUCTION}

The world economic order has experienced rapid change in its economic growth in accordance with its natural and human base resources. Alvin Toffler describes this phenomenon by dividing economic civilization into four waves: agricultural, industrial, information, and creative. According to Howkins (2002), the economic model makes use of creativity in generating benefits.

Creative industries are the main component of the economy, with humans as drivers of economic development and innovation of new ideas. Moreover, efforts to visualize creativity as a mental activity, using non-traditional approaches and different thoughts, are often associated with originality and discovering new ways to overcome problems. Thus, the exploitation of human creativity that frames and maintains an ethical and sustainable economy has become a significant focus for developing innovative concepts, designs, and entrepreneurship (Petrikova et al., 2015).

Malang is an area with many creative economic potentials, ranging from human resources to traditional culture. Over the last few years, there has been significant growth in its creative industry, as shown in the positive graph. Geographically, Malang benefits from the natural beauty of the surrounding areas such as Batu City with its agro-tourism, Selecta baths, and Songgoriti, ancient sites from the Singosari
Kingdom. Moreover, a close distance from the capital of East Java Province has made this city a haven and shopping for travelers (Hastuti et al., 2019).

The outreach report and facilitated registration of intellectual property rights for creative economic actors show that the city has several excellent potentials such as fashion, design, crafts, culinary, games and application, music, performing arts. In addition, the Indonesian Creative Economy Board (2019) stated that the government had made various efforts to encourage Malang as a creative city through capital facilitation, technology, and marketing. Figure 1 describes the percentage of creative subsectors in Malang.

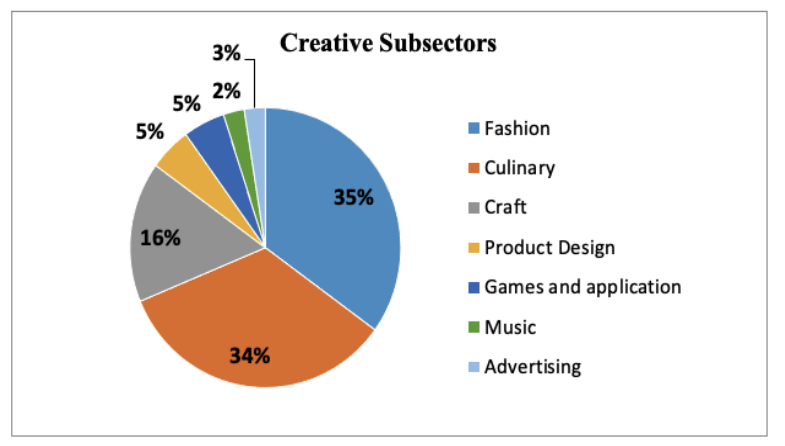

Figure 1. Percentage of creative subsectors in Malang 
Three crucial aspects need to be considered to develop a creative city. They include a strong relationship related to the growth of the creative economy, its maintenance, and the provision of a conducive environment. For instance, the creative class consists of actors that are actively involved in the development process. They play roles in which their creativity leads to products with intellectual property that has commercial value. Therefore, to develop and produce original products, a conducive and inspirational environment for the creative class is essential. These relations make the three aspects necessary and enable the development of Malang into a creative city.

The city of Malang is a medium for its residents to perform activities, innovate, and be creative. Therefore, this is an essential factor in urban economic development. However, according to Carta (2007), creative behavior in the city economy needs simultaneous support from all elements of government, economic actors, and society.Etzkowitz and Leydesdorff introduced the Triple Helix model, which stated that the industry or business is the actor responsible for creating innovation (Etzkowitz \& Leydesdorff, 1995). Furthermore, they reported that the academic sector is responsible for creating knowledge that interacts with the government. The three actors work together through a topdown approach to develop innovations that improve a country's economic conditions (Praswati, 2017). Thus, innovation spearheads the competitiveness and economic growth of a country with the creator known by the helix concept. The concept emphasizes that innovation is an outcome involving the interaction and collaboration of various types of creative actors. Carayannis and Campbell (2010) reported the importance of government policies, universities, industries, and civil society to interact intelligently, effectively, and efficiently.

In parallel, the Quadro Helix concept development was achieved by maintaining academics, business, and government interaction with civil society (Roman et al., 2020). Academics and companies develop the atmosphere needed for a cohesive innovation environment. Meanwhile, the government supports them by providing regulations as a legal basis and financial support for implementing policies and innovative strategies. Civil society plays an active role in developing and implementing innovative knowledge in services and goods.

The Quadro Helix Model is a design for integrating and coordinating four creative actors (Hendarman \& Tjakraatmadja, 2012). It focuses on how actors that include Academics, Business, Community, Government (ABCG) contribute to developing the creative economy, which becomes the foundation of a creative city. The communication that engages all actors becomes crucial with its development. This model emphasizes how each actor contributes to the development and strategies to eliminate obstacles. Therefore, this research determines the synergy of these actors in the creative city through the communication model.
Several studies have been carried out on the creative city, with some focusing on how it has become the creative space for citizens (Michels et al., 2014; Motcanu-Dumitrescu, 2017) and its actors (Baum, 2018; Borén \& Young, 2017; Konno \& Itoh, 2017). Other studies focused on the image (Das, 2016; Prilenska, 2012; Vanolo, 2015), with little consideration of studies associated with the creative city and communication (Foth \& Hern, 2007). Furthermore, no study has bee conducted to address the issue associated with the communication model among creative actors. An understanding of the model of communication developed among creative actors is fundamental in creating a conducive environment. According to Landry (2012), the most critical city resources are the people. This research aims to analyze Malang's development as a creative city through the interaction of Quadro helix actors based on the optimal implementation of the public relations model. Further, the process of communication and the roles of creative actors were also identified.

The Public Relations Society of America (PRSA) describes public relations as a strategic communication process to develop a long-term mutual understanding between organizations and the public (Elliott, 2012). However, there was a tendency to perform certain functions in carrying out these practices, which led to model forming.

Grunig and Hunt (1984) stated that four models were associated with public relations communication practices. There are two dimensions of the models, namely, nature (oneway versus two-way) and purpose (asymmetrical/unbalanced versus symmetrical/balanced) of communication (Gürel \& Kavak, 2010). Table 1 briefly describes the four models in accordance with their purpose, nature, and model of communication, as well as the philosophical worldview and estimation used by the organization.

Table 1. Public Relations Models

\begin{tabular}{|l|l|l|l|l|}
\hline Characteristic & \multicolumn{4}{|c|}{ Public Relations Models } \\
\cline { 2 - 5 } & Press Agentry & $\begin{array}{l}\text { Public } \\
\text { Information }\end{array}$ & $\begin{array}{l}\text { Two-way } \\
\text { asymmetrical }\end{array}$ & $\begin{array}{l}\text { Two-way } \\
\text { symmetrical }\end{array}$ \\
\hline Purpose & Propaganda & $\begin{array}{l}\text { Dissemination } \\
\text { of Information }\end{array}$ & $\begin{array}{l}\text { Scientific } \\
\text { persuasion }\end{array}$ & $\begin{array}{l}\text { Mutual } \\
\text { understanding }\end{array}$ \\
\hline $\begin{array}{l}\text { Nature of } \\
\text { communication }\end{array}$ & $\begin{array}{l}\text { One way, truth } \\
\text { inessential }\end{array}$ & $\begin{array}{l}\text { One way, truth } \\
\text { important }\end{array}$ & $\begin{array}{l}\text { Two way, } \\
\text { imbalanced } \\
\text { effects }\end{array}$ & $\begin{array}{l}\text { Two way, } \\
\text { mutual } \\
\text { understanding }\end{array}$ \\
\hline $\begin{array}{l}\text { Communication } \\
\text { model }\end{array}$ & Source $\rightarrow$ Rec. & Source $\rightarrow$ Rec. & $\begin{array}{l}\text { Source } \rightarrow \text { Rec. } \\
\leftarrow \\
\text { Feedback }\end{array}$ & $\begin{array}{l}\text { Group } \rightarrow \text { Group } \\
\leftarrow\end{array}$ \\
\hline $\begin{array}{l}\text { Philosophical } \\
\text { worldview }\end{array}$ & Asymmetrical & Asymmetrical & Asymmetrical & Symmetrical \\
\hline $\begin{array}{l}\text { Estimation used } \\
\text { by the } \\
\text { organization }\end{array}$ & $15 \%$ & $50 \%$ & $20 \%$ & $15 \%$ \\
\hline
\end{tabular}

Source: James E Grunig \& Todd Hunt. 1984. Managing Public Relations. Holt Rinehart \& Winston: Fort Worth. p. 22

Although all four models emerged along with public relations development, various organizations practice the models alternately. The use of these models depends on the objectives to be achieved by the organization. Grunig and Hunt's 1984 research showed that $50 \%$ of all organizations adopted the one-way communication practice (public 
information) to their stakeholders, and only $35 \%$ utilized the two-way. Out of the four models, organizations tend to use the last three because they suit in a more critical and engaging environment. Morsing and Schultz (2006) identified three communication strategies out of these four public relations models: stakeholder information, actors response, and engagement strategies (Morsing \& Schultz, 2006: 325).

However, this research focuses on how Malang's creative actors inform, supervise, collaborate, and empower each other to develop a creative city that leads to the communication model used. It also determines the roles of each creative actor. Adopting the communication model of public relations provides a new approach in the examination of creative city development.

\section{METHOD}

This research adopted a qualitative method to determine an event's practice, significance, and perception from the participants' viewpoint (Hammarberg et al., 2016). Guba \& Lincoln (2000) characterized qualitative research as an interpretive and naturalistic method that focuses on examine things in the natural environment.

Specifically, this study embraced a case study that, according to Cavus and Juma'h (2001), concentrates on understanding the dynamics in a single setting. It scientifically explores in-depth, real-life phenomena within its setting (Ridder, 2017). According to Pinfield (1986), case studies consist of cases and various analysis levels to provide a detailed description. This study's first step was to outline the case study, incorporate case study objectives, issues, literature review, and tangible resources to create sources of sustainable competitive advantage (Gaya, 2016).

The second step was data collection. This research adopted in-depth interviews, focus group discussion, and participatory data gathering techniques. It was carried out in Malang city with some creative actors: Malang Tourism and Creative Economic Agency, Malang Creative Fusion, Academics from Brawijaya University, and Association of Malang Graphic Design. Some interviews were conducted online, while others were conducted in Malang. The collected primary data focused on determining how creative actors adopted the Quadro helix concept within the public relations model's perspective. The study also proposed communication models of creative city development that synergize creative actors.

The third step was the data analysis. This research used qualitative data analysis where the gathered data was classified based on level of importance, displayed, and concluded.

\section{RESULT AND DISCUSSION}

\subsection{The Potentials of Malang as a Creative City}

It is noteworthy that the development of a creative city principally relates to economic potentials and community groups. These efforts started in 2009 with the launch of Indonesia Creative Year and the Ministry of Tourism and Creative Economic existence at the national level. Therefore, the efforts of the government and creative actors in the development of creative cities are essential. Furthermore, the government also founded a Creative Economy Agency to support the development of the creative economy. As a facilitator, the government needs to support all efforts carried out by creative actors in improving the welfare of society.

In 2014, the Indonesian government facilitated the formal inception of the Indonesian Creative City Network, Bandung and Surakarta, as the City of Design, Malang, and Pekalongan as a craft and folk art city. So, in the end, the cities that joined the ICCN are Pekalongan and Bandung.

The creative economy is an opportunity for the areas not to rely on tourism to increase their local revenue. Based on Creative Economic Statistics 2016 from the collaboration between Creative Economic Agency and Central Bureau of Statistics, from 2010-2015, the creative economy GDP went up from IDR 525.96 trillion to IDR 852.24 trillion. Furthermore, in 2015, the creative economy contributed $7.66 \%$ to national economic growth (Fau, 2017). The data from the Central Bureau of Statistics of Malang in the 2016 Economic Survey showed 40,690 creative economy actors in Malang. The top three developing sub-sectors include the culinary, fashion, and craft subsectors of 28,398, 7,295, and 2,989, respectively (Ratri, 2019).

Indonesia is a country with a variety of ethnic groups comprising unique art and cultural products. Therefore, Malang is considered worthy of bearing the world's most creative city due to its numerous advantages besides its cultural heritage, diversity, religion, and ethnicity.

Malang is also an educational city with many universities and a significant tourist destination in Indonesia. All these attributes contribute to the support of the creativity of its people.

The creative economy sector in Malang has undergone rapid growth over the last two years, with games and applications as the most developed subsector. In 2017, there were 92 startups and studios in this field, which rapidly increased to 151 companies within two years. Currently, the game and application subsector can absorb more than 2200 workers. The significant development of the creative economy sector also led to the nomination of Malang city as an original area (Ramadana, 2019). This subsector has been growing and developing since 2011 against the background of the information technology industry's primary knowledge character. Educational institutions actively contributed to the development of this subsector with more than ten departments of information technology. It was the collaboration between 
academics and community groups of developers in this subsector that encouraged government support. The business sector later came with the provision of funds and motivations.

The major players of this sub-sector in the Malang City area include community, academic, entrepreneur, government, and business people. Zulfikar (2017) stated that the processes undertaken include creation, production, distribution, consumption, and conservation. The argument behind this selection was that the world is now living in an era of online systems (cyber-physical systems), IoT (internet of things), and networking. These three definitive concepts form a new economic structure called the creative economy, with the industry known as the creative industry.

The game and application subsector accommodates scholars from various majors such as psychology, management, and art. In the future, this subsector is likely to be an ideal reference for the creative economy.

The first phase of the Malang government in developing the Creative City was by involving Quadro helix actors to design and develop a road map. The government realized that the support of creative city actors was essential because each plays a critical role. Therefore, to support this process, the government issued regulation number $12 / 2018$ as the foundation for creating a road map. Figure 1 shows the creative economic subsectors that support the achievement of the vision and mission of the government, as stated in the Regional Mid Term Development Plan.

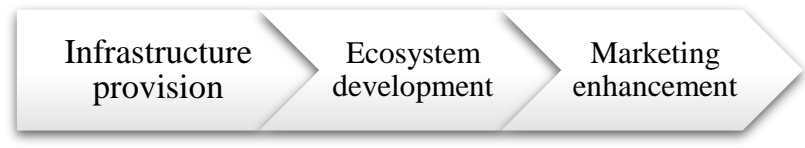

Figure 2. Road map for Malang Creative City development

The goals for the creation of this road map are in two folds. Firstly, it acts as a guideline for creative economy actors to determine the programs or activities within Malang's developmental framework. Secondly, it acts as a means of monitoring and evaluating creative economy actors to implement all programs or activities.

The regulation also emphasized the importance of engaging all relevant actors in developing the creative city. This also signifies their awareness in assisting the development of Malang as a creative city. It also determines how they communicate with one another and what type of public relations model was adopted.

\subsection{The Synergy of Quadro Helix Actors: Public Relations Model}

Humans are the central element in developing creative cities due to their ability to embody concepts, ideas, thoughts, knowledge, talents, and skills as art and work. They are grouped and appreciated according to their respective professions and abilities. In the context of the development of a creative city, these groups are creative actors involved in a model known as the Quadro helix. Developing and building an innovative city tends to occur, assuming each actor can collaborate and work together following their respective roles.

Halibas et al. (2017) stated that Quadro helix is a strategy that involves various community or non-profit institutions to create innovation. Therefore, through synergistic collaboration, it is possible to realize an innovation supported by various resources.

The government of Malang can emphasize the synergy and role of Quadro helix actors by having a regulation that becomes the foundation for developing a creative city. The local government acts as a facilitator and initiator of creative economic development in Malang City. Meanwhile, academics act as facilitators in developing human resources based on the needs of the creative industries. Furthermore, the community, which is also the sub-sector of the economy, acts as a facilitator and liaison between business people with the Regional Government and Higher Education in developing the creative economy. Business actors act as objects to collaborate and work together with other supporting components such as the Local Government, Academics, and Communities.

Therefore, the development of Malang as a creative city through the interaction of its Quadro helix actors aims at examining the communication processes involved. The public relations models adopted to analyze the communication process describes the predetermined goals. Further, the analysis looks at the role of each actor in contributing to the creative city development.

Based on the data collection, the process of communication that took place among creative actors of Malang involved three models. They were engagement communication, response communication, and public information models.

\subsubsection{Engagement Communication Model}

This model is similar to the two-way symmetrical model of Grunig. It emphasizes the importance of changing organizational behavior to respond to public demands. However, some assumptions are attached to this engagement communication model, such as telling the truth, interpreting the wishes of the client and public, and understanding each creative actor (Grunig, 2013).

This communication occurs as each actor realizes the necessity to engage and contribute ideas in the development process of a creative city by involving academics, businesses, the community, and the government. The communication tactics used include the hearing forum in the local house of representatives, focus group discussion, and informal consultation. The government and academics act as initiators 
and persuasive toward others. They formed a forum to identify issues required for creative city development. Thus, the communication occurred to achieve mutual understanding. Furthermore, the goals of the communication through the forum were to collaborate and to empower.

One of the crucial outputs of engagement communication was Government Regulation number 12/2018, which is essential in supporting a creative economy that becomes the backbone of a city. The regulation outlined all developed programs, with each actor responsible for designated attachment. The output of this engagement communication is the agreement on 45, 34, and 55 short, medium, and long-term programs. In addition, the program includes plans to build a Malang Creative Center in 2020 (Ramadana, 2019).

Another output was the timeline of creative economic development as the key to a creative city. The first period was the year 2018 to 2019, focusing on single game and application industry data. This period is known as the Synergy of Malang. The second period is the year 2020 to 2021. Known as the Empower of Malang, this period emphasizes strengthening human resources. The characteristic of this period is the certification of human resources based on the industry needs. The last period of the timeline is the year 2022 to 2023. With the spirit of Malang goes Global, this period requires all creative actors to grow and attract global corporations to invest in Malang.

\subsubsection{Response Communication Model}

This refers to the two-way asymmetric model of public relations. Communication acts as feedback or response in determining what is accepted and tolerated by the actors. It is an evaluative form to measure whether specific communication initiatives have increased the actors' understanding of the company and vice versa (Morsing \& Schultz, 2006b). One feature of this model is the scientific approach, and this study identifies the use of some research to obtain responses from relevant actors. The results form the basis for the Quadro helix forum of Malang City in determining relevant programs.

One of the studies included determining gaming and application as the primary subsector with two-way asymmetrical communication through focus group discussion and in-depth interviews. The Quadro helix forum provided the requested proposal to the Indonesian Creative Agency through the Self-Assessment program. Providing data and information on market access and expansion, technology and infrastructure, human resources, raw materials, industry, financing, and institutional is essential (Fitri, 2018).

This activity resulted in signing an official report by the Deputy for Infrastructure, the Mayor of Malang, the Creative City Self-Assessment Assessor Team, representatives from the Application \& Games subsector, and Tourism and Creative Agency. This signing symbolized a commitment from the Regional Head to advance the creative economy, especially in the game and application subsector.

\subsubsection{Public Information Model}

This communication model aims to disseminate information to the public (Grunig \& Hunt, 1984, p. 23). Therefore, the one-way communication public information strategy aims to disseminate objective information regarding the organization (Morsing \& Schultz, 2006).

This one-way communication was adopted to announce government regulation, promote programs for creative community groups, invite Quadro helix actors to join the forum, and others. Advertising, media relations, emails are some of the techniques adopted by the Quadro helix forum of Malang Creative City. The public information strategy assumes that all actors can support buying habits, loyalty, and appreciating government efforts. Therefore, the Quadro helix forum needs to continuously inform actors on good intentions, decisions, and actions to ensure positive support from actors.

Each creative actor ideally contributes to the city's development based on their capabilities through suggestions, collaborations, and discussions. Interestingly, the Quadro helix forum was unaware that it had adopted a combination of these three communication models in one program. Evidence of this was the organization of a program called "Socialization and facilitation of registration of intellectual property rights for the creative community groups" held in mid-2019, which incorporated speakers of central and local governments. The discussion that followed was an engagement communication model as inputs from speakers, community groups, and academics, which tends to bring changes to all sides, possibly. At the end of the program, a survey related to creating economic development services was a response communication model.

The various and robust communication among actors led to the declaration of Malang as a creative city in 2019 by the Indonesian Creative Agency, with the game and application subsector as the main characteristic.

Based on the three communication models that occurred among creative actors in Malang, this study identified the communication process as shown in Figure 2.

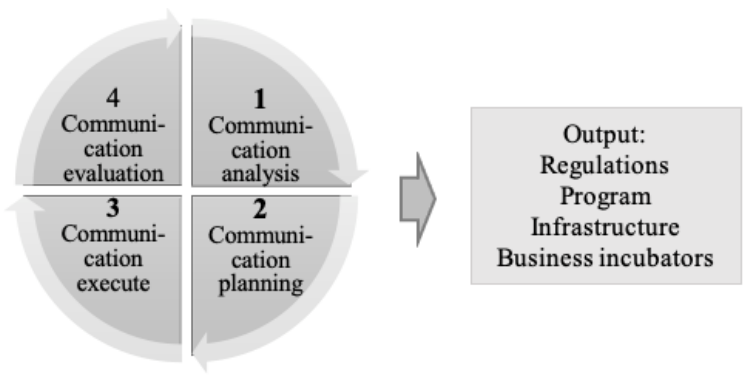

Figure 3. Communication planning for Malang Creative City development

The structured communication process has enabled creative actors to identify problems or conditions to achieve 
and decide the communication tactics used to achieve specified goals.

Also, this process helped them to identify their roles and provide necessitated evaluation.

Table 2. Roles of creative actors of the City of Malang

\begin{tabular}{|c|c|c|c|}
\hline & $\mathrm{Bu}$ & $y$ & it \\
\hline $\begin{array}{l}\text { - Creation of } \\
\text { creative human } \\
\text { resources } \\
\text { - Development, } \\
\text { utilization, and } \\
\text { distribution of } \\
\text { knowledge } \\
\text { - Appreciation } \\
\text { and literacy in } \\
\text { creativity }\end{array}$ & $\begin{array}{l}\text { - Industrial } \\
\text { - Creation of } \\
\text { markets, creative } \\
\text { goods and } \\
\text { services, and } \\
\text { employment } \\
\text { - Research and } \\
\text { development } \\
\text { - Forming } \\
\text { community and } \\
\text { creative } \\
\text { entrepreneurship }\end{array}$ & $\begin{array}{l}\text { - Forum of } \\
\text { various } \\
\text { knowledge } \\
\text { - Forum for the } \\
\text { development } \\
\text { of creative } \\
\text { networks } \\
\text { - The place for } \\
\text { expression } \\
\text { and } \\
\text { exploration of } \\
\text { creativity }\end{array}$ & $\begin{array}{l}\text { - Regulator: } \\
\text { establish } \\
\text { and control } \\
\text { policies } \\
\text { - Facilitator/ } \\
\text { Accelerator: } \\
\text { support, } \\
\text { incentives, } \\
\text { and } \\
\text { convenience }\end{array}$ \\
\hline
\end{tabular}

Table 2 shows that creative actors need to be aware of their responsibilities and roles to achieve a creative city. A clear division of responsibility is necessary for the synergy to occur.

In sum, the actors adopted three models of public relations, namely, the engagement of communication, response communication, and public information models to develop programs based on the nature of communication to inform, supervise, collaborate and empower goals. The engagement communication model was used more often than other models, as the Quadro helix requires intense communication among creative actors. The formation of a forum is necessary to synergize ideas from all relevant actors.

The study of the communication model in creative city development is relatively new. Therefore, it contributes to the extensive use of communication in the development of new concepts.

\section{ACKNOWLEDGMENTS}

The authors would like to thank the Ministry of Cultural and Education of the Republic of Indonesia for providing funds for this research. Our gratitude also goes to the Institute for Research and Community Service at Universitas Pembangunan Nasional "Veteran" Yogyakarta, Indonesia, for helping us complete administrative matters.

\section{REFERENCES}

[1] Howkins, J. (2002). The Creative Economy: How People Make Money from Ideas. Penguin UK.
[2] Petrikova, K., Vanova, A., \& Borsekova, K. (2015). The role of creative economy in Slovak Republic. AI \& Society; London, 30(2), 271-281. http://dx.doi.org/10.1007/s00146-013-0508-5

[3] Hastuti, T., T, M. A., \& Puspitasarie, E. (2019). Strategi Pengembangan Ekonomi Kreatif Di Malang Raya. Conference on Innovation and Application of Science and Technology (CIASTECH), 2(1), 11-20.

[4] Carta, M. (2007). Creative City. Dynamics, Innovations, Actions.

https://www.academia.edu/1639648/Creative_City_Dynamics _Innovations_Actions

[5] Etzkowitz, H., \& Leydesdorff, L. (1995). The Triple HelixUniversity-Industry-Government Relations: A Laboratory for Knowledge Based Economic Development by Henry Etzkowitz, Loet Leydesdorff: SSRN. https://papers.ssrn.com/sol3/papers.cfm?abstract_id=2480085

[6] Praswati, A. N. (2017). Perkembangan Model Helix Dalam Peningkatan Inovasi. 16.

[7] Carayannis, E. G., \& Campbell, D. F. J. (2010). 'Mode 3' and 'Quadruple Helix': Toward a 21st century fractal innovation ecosystem. International Journal of Technology Management, 46(3-4), 201-234. https://doi.org/10.1504/IJTM.2009.023374

[8] Roman, M., Varga, H., Cvijanovic, V., \& Reid, A. (2020). Quadruple Helix Models for Sustainable Regional Innovation: Engaging and Facilitating Civil Society Participation. Economies, $8(2), \quad 48$. https://doi.org/10.3390/economies8020048

[9] Hendarman, A. F., \& Tjakraatmadja, J. H. (2012). Relationship among Soft Skills, Hard Skills, and Innovativeness of Knowledge Workers in the Knowledge Economy Era. Procedia - Social and Behavioral Sciences, 52, 35-44. https://doi.org/10.1016/j.sbspro.2012.09.439

[10] Michels, C., Beyes, T., \& Steyaert, C. (2014). Another new museum? Imagining the space of art in the creative city. Scandinavian Journal of Public Administration, 18(3), 9-28-28.

[11] Motcanu-Dumitrescu, M. (2017). A Creative City Is a Liveable City. Journal of Urban and Landscape Planning, 2, 41-48.

[12] Baum, T. (2018). Changing employment dynamics within the creative city: Exploring the role of 'ordinary people' within the changing city landscape-Strathprints. https://strathprints.strath.ac.uk/62181/

[13] Borén, T., \& Young, C. (2017). Artists and creative city policy: Resistance, the mundane and engagement in Stockholm, Sweden. City, Culture and Society, 8, 21-26. https://doi.org/10.1016/j.ccs.2016.05.002

[14] Das, D. K. (2016). Engendering Creative City Image by Using Information Communication Technology in Developing Countries. https://www.ssoar.info/ssoar/handle/document/58391

[15] Prilenska, V. (2012). City Branding as a Tool for Urban Regeneration: Towards a Theoretical Framework. Architecture and Urban Planning, 6(0), 12-16. https://doi.org/10.7250/aup.2012.002

[16] Vanolo, A. (2015). The image of the creative city, eight years later: Turin, urban branding and the economic crisis taboo. 46, 1-7. https://doi.org/10.1016/j.cities.2015.04.004

[17] Foth, M., \& Hern, G. M. (2007). Networked individualism of urban residents: Discovering the communicative ecology in 
inner-city apartment buildings | QUT ePrints. https://eprints.qut.edu.au/6100/

[18] Landry, C. (2012). The Creative City: A Toolkit for Urban Innovators. Earthscan.

[19] Elliott, S. (2012, March 1). Public Relations Defined, After an Energetic Public Discussion. The New York Times. https://www.nytimes.com/2012/03/02/business/media/publicrelations-a-topic-that-is-tricky-to-define.html

[20] Grunig, J. E., \& Hunt, T. (1984). Managing public relations. https://www.worldcat.org/title/managing-publicrelations/oclc/315608524?loc $=94043 \&$ tab $=$ holdings\&start_ho lding $=7$

[21] Gürel, E., \& Kavak, B. (2010). A conceptual model for public relations in museums. European Journal of Marketing, 44(12), 42-65. https://doi.org/10.1108/03090561011008600

[22] Morsing, M., \& Schultz, M. (2006). Corporate social responsibility communication: Stakeholder information, response and involvement strategies. Business Ethics: A European Review, 15(4), 323-338. https://doi.org/10.1111/j.1467-8608.2006.00460.x

[23] Hammarberg, K., Kirkman, M., \& de Lacey, S. (2016). Qualitative research methods: When to use them and how to judge them. Human Reproduction, 31(3), 498-501. https://doi.org/10.1093/humrep/dev334

[24] Guba, E. G., \& Lincoln, Y. S. (2000). Paradigmatic Controversies, Contradictions, and Emerging Confluences. ResearchGate.

https://www.researchgate.net/publication/232427764_Paradig matic_Controversies_Contradictions_and_Emerging_Conflue nces

[25] Cavus, M., \& Juma'h, A. H. (2001). Describing case study method and identifying the factors that contribute to the successful conduct of case studies. https://dire.upr.edu/handle/11721/1333

[26] Ridder, H.-G. (2017). The theory contribution of case study research designs. Business Research, 10(2), 281-305. https://doi.org/10.1007/s40685-017-0045-Z

[27] Pinfield, L. T. (1986). A Field Evaluation of Perspectives on Organizational Decision Making. Administrative Science Quarterly, 31(3), 365-388. $\quad$ JSTOR. https://doi.org/10.2307/2392828

[28] Gaya, D. H. (2016). Developing a Qualitative Single Case Study in the Strategic Management Realm: An Appropriate Research Design? 7, 10.

[29] Fau, T. N. (2017). Gaet Potensi Pariwisata Yogyakarta dari Ekonomi Kreatif. https://www.google.com/search?q=http $\% 3 \mathrm{~A} \% 2 \mathrm{~F} \% 2$ Fvalidne ws.co\%2FGaet-Potensi-Pariwisata-Yogyakarta-dari-EkonomiKreatif-V0000079\&ie $=$ utf- 8 \&oe $=$ utf- $8 \&$ client $=$ firefox-b

[30] Ratri, N. (2019). Potensial, Kota Malang Punya 40 Ribu Lebih Pelaku Ekonomi Kreatif | MalangTIMES. https://www.malangtimes.com/baca/39528/20190517/113100/ potensial-kota-malang-punya-40-ribu-lebih-pelaku-ekonomikreatif

[31] Fitri, A. N. (2018, July 9). Profil Kota/Kabupaten KreatifKota Malang. indiekraf.com. https://indiekraf.com/profilkotamalang/

[32] Grunig, J. E. (2013). Excellence in Public Relations and Communication Management. Routledge.

[33] Ramadana, A. (2019). Ekonomi Kreatif Berkembang Pesat, Kota Malang Masuk Nominasi Kota Kreatif. https://jatim.idntimes.com/news/jatim/alfi-ramadana/ekonomikreatif-berkembang-pesat-kota-malang-masuk-nominasi-kotakreatif/1 